\title{
El discernimiento de espíritus en las periferias cristianas: pactos, daños y gozo entre aborígenes evangélicos del Chaco Argentino
}

\author{
Agustina Altman \\ Universidad de Buenos Aires \\ FLACSO-CONICET \\ a_altman@hotmail.com
}

\section{RESUMEN}

El discernimiento de espíritus ha sido a lo largo de la historia del cristianismo un mecanismo fundamental para el control del acceso al carisma. Su desarrollo ha estado profundamente ligado a los cambios en la estructura social de las iglesias. Por ello buscamos aportar nuevas miradas sobre este dispositivo, analizándolo en el contexto de las periferias cristianas. Específicamente centraremos nuestro análisis en las iglesias evangélicas aborígenes mocoví del suroeste de la provincia del Chaco en Argentina. Nos aproximaremos a estas cuestiones a partir del análisis a la estructura social de estas iglesias, sus concepciones sobre los vínculos con las potencias no-humanas, la gestión de salud y enfermedad y la experiencia del culto.

Palabras clave: Discernimiento de espíritus, carisma, periferias cristianas, aborígenes, evangélicos, Argentina.

\section{Discernment of Spirits in Christian peripheries: pacts, harm and joy among evangelical Indians from Argentinian Chaco}

\begin{abstract}
The discernment of spirits has been throughout history a key mechanism to control the access to charisma. Its development has been closely linked to the changes in the social structure of churches. That is why, we will seek to provide new perspectives on this device, analyzing it in the context of Christian peripheries. Specifically, we will focus our analysis on mocoví aboriginal evangelical churches from the Southwest of Chaco province in Argentina. We will approach these topics by analyzing the social structure of these churches; their ideas about the relationship with non-human powers of the sacred; the management of health and disease and their cult's experience.
\end{abstract}

Keywords: Discernment of spirits, charisma, Christian peripheries, evangelism, aboriginal people, Argentina.

SUMARIO: 1. Introducción. 2. Esbozo de una historia del discernimiento de espíritus. 3. Los mocoví.

4. Discernimiento de espíritus y estructura social en las iglesias evangélicas aborígenes del Chaco.

5. Humanos y no-humanos. 6. Salud y enfermedad. 7. El culto. 8. Conclusiones. 9. Bibliografía. 


\section{INTRODUCCIÓN}

El discernimiento de espíritus ha sido a lo largo de la historia del cristianismo un dispositivo fundamental para el control del carisma. Como tal su desarrollo esta profundamente ligado a los cambios acontecidos en la estructura social de las iglesias cristianas.

En este trabajo, nos proponemos analizar las formas que adquiere el discernimiento de espíritus en el contexto de las iglesias evangélicas mocoví en el Chaco argentino. Creemos que la situación particular respecto al poder y a la organización eclesial en estos contextos coloniales y poscoloniales puede aportar nuevas miradas sobre la dinámica general del discernimiento de espíritus como mecanismo regulador en el cristianismo. Nuestro análisis estará centrado en el movimiento del evangelio ${ }^{1}$ el cual se originó a partir del encuentro entre grupos toba y misioneros evangélicos y pentecostales que arribaron al Chaco bajo diferentes emprendimientos religiosos durante las décadas de 1930 y 1940. Sin embargo, recién para fines de 1970 las iglesias evangélicas - principalmente la Iglesia Evangélica Unida (IEU) ${ }^{2}$ - cobraron importancia entre las comunidades mocoví (moqoit) del $\mathrm{Chaco}^{3}$.

El evangelio entre los aborígenes de las provincias de Chaco y Formosa ha ocupado un papel clave en las resignificaciones en torno a las pautas morales, la cosmovisión e instituciones políticas de estos grupos. Esta creación cultural, caracterizada por la centralidad que confiere a las experiencias extáticas (cantos, danzas, sesiones de curación, glosolalia, etc.), surgió de una compleja interacción entre elementos del cristianismo evangélico -especialmente pentecostal-y del shamanismo tradicional ${ }^{4}$.

Nos aproximaremos a estas cuestiones a partir del análisis de la estructura social de las iglesias evangélicas mocoví; sus concepciones sobre los vínculos con las potencias no-humanas; la gestión de salud y enfermedad; y la experiencia del culto. En tanto que estas dimensiones estructuran al discernimiento de espíritus entendido como un dispositivo de control del acceso al carisma, las mismas serán cruciales para entender las formas que este toma entre los aborígenes evangélicos del Chaco.

\section{ESBOZO DE UNA HISTORIA DEL DISCERNIMIENTO DE ESPÍRITUS}

Como señalamos en la introducción, el discernimiento de espíritus ha sido a lo largo de la historia del cristianismo un dispositivo fundamental para el control del

\footnotetext{
${ }^{1}$ Evangelio es una categoría nativa polisémica que hace referencia a todas las denominaciones evangélicas que los aborígenes guaycurú contactaron, alude a las Iglesias aborígenes como la Iglesia Evangélica Unida u otras no indígenas como la Iglesia Cuadrangular e indica la condición ontológica del creyente. Este tema esta ampliamente desarrollado en Wright 2008a, 193s.

2 Institución central para el movimiento del evangelio chaqueño. La Iglesia Evangélica Unida, fue la primera iglesia aborigen inscripta en el registro de cultos de Argentina en 1961. Los Obreros Fraternales Menonitas fueron centrales en el establecimiento de dicha institución.

3 Altman 2011, 127-143.

${ }^{4}$ Ceriani Cernadas y Citro 2005, 113.
} 
carisma. La ambigüedad del concepto sirvió de vehículo a diversas interpretaciones que buscaron controlar uno de los principales capitales simbólicos en el contexto de las iglesias cristianas: el contacto con las fuentes sobrenaturales del conocimiento y la experiencia religiosa.

A pesar de que a lo largo del tiempo muy diversas concepciones sobre el control del acceso al carisma se han disputado la definición del «discernimiento de espíritus», en cada etapa de este proceso se ha pretendido presentar a este dispositivo de control como resultado de una tradición homogénea. Con el objeto de comprender la forma en que el discernimiento de espíritus ha sido socialmente construido y el rol que ha desempeñado, realizaremos una breve síntesis de la historia social del mismo, siguiendo el análisis del historiador Fabián Campagne ${ }^{5}$. Esto nos permitirá dar cuenta de ciertas disputas en el seno del cristianismo que son claves para comprender el rol de este dispositivo en el contexto del evangelio moqoit.

Como señala Campagne ${ }^{6}$, la discretio spirituum ha basado su fundamento bíblico en una serie de versículos neo-testamentarios: 2 Corintios 11:14; 1 Tesalonicenses 5:19-22; 1 Juan 4:1; 1 Corintios 12:10. El primer versículo hace eferencia a la capacidad de Satanás de engañar y adoptar la apariencia de entidades benévolas y la necesidad de desenmascararlo. El segundo y el tercero mencionan la necesidad de examinar y poner a prueba los espíritus y falsos profetas para desenmascarar las artimañas del Enemigo. El cuarto versículo puede ser considerado como fundacional ya que aparece de manera literal el término discernimiento de espíritus. El mismo es mencionado por San Pablo dentro de un listado de dones extraordinarios que la divinidad otorga como una gracia gratis data: «A otro, el hacer milagros; a otro, profecía; a otro, discernimiento de espíritus; a otro, diversos géneros de lenguas; y a otro, interpretación de lenguas».

Si bien las referencias al discernimiento de espíritus son ambiguas y no emanan naturalmente del texto sagrado así como los criterios prácticos que aparecen se contradicen o anulan, siguiendo a Campagne ${ }^{7}$ podemos distinguir tres grandes interpretaciones históricas acerca de la discretio spirituum. Una de ellas consiste en considerar al discernimiento de espíritus como la capacidad de determinar si las experiencias sobrenaturales, las profecías, visiones, éxtasis, apariciones son de origen divino, diabólico o humano. Esta línea de interpretación va a dominar en dos etapas: desde el siglo II al $\mathrm{V}$ en donde se realizaran prácticas de autodiscernimiento con el fin de poner a prueba las propias experiencias extraordinarias y del siglo XIV al XVII donde tendrá un uso sobre terceros y será utilizado como un dispositivo de control. La segunda línea de interpretación del discernimiento de espíritus está vinculada a la capacidad de conocer los pensamientos ocultos de los hombres, sus pecados secretos y el estado de sus almas en atención a la dirección espiritual. Esto aparece en el contexto de las comunidades cenobíticas ligado al ejercicio por parte del abad de su rol como guía en el

\footnotetext{
${ }^{5}$ Campagne 2014, 19-74.

${ }^{6}$ Campagne 2014, 19-22.

7 Campagne 2014, 20-22.
} 
camino espiritual de los monjes. De hecho, la vida en pequeñas comunidades buscaba evitar los abusos, arrebatos y locuras a las que frecuentemente llevaba el aislamiento eremítico que dejaba todo librado a la inspiración de cada persona. Esta línea de interpretación también tiene un carácter disciplinador. La última línea de interpretación está vinculada a la capacidad de determinar el origen de las mociones interiores, los impulsos interiores que motivan las acciones de las personas, con el fin de corroborar si son o no voluntad de Dios. Esta última línea surge en la modernidad con la idea de individuo y puede encontrarse hoy en día entre las iglesias pentecostales ${ }^{8}$.

De estas tres grandes líneas de interpretación, surgieron tres maneras de discernir. La primera podemos encontrarla en las hagiografías del primer y segundo milenio donde aparecen ciertos personajes como santos dotados de capacidad para ver el mundo sobrenatural. La segunda, en la tardía edad media y en la primera modernidad estará ligada a la invención del purgatorio y con la capacidad de los santos de ver el estado del alma del difunto como así también, poder discernir sobre el destino postmortem de las almas. La tercera línea, surgida en la segunda mitad del primer milenio, conceptualiza al discernimiento como sinónimo de prudencia entendida como una virtud monástica que permite evitar excesos y defectos.

Uno de los textos centrales del cristianismo en el que se hace referencia al discernimiento de espíritus, que destaca Campagne ${ }^{9}$ en su análisis sociológico sobre las tensiones entre institución y carisma, es la Didaché (70-110dc.). Allí se menciona la importancia de los profetas, los cuales son tratados como sumos sacerdotes, y se menciona como criterio para distinguir a los verdaderos profetas el tipo de conductas que estos tenían y el ascetismo. Hacia la segunda mitad del siglo I nos encontramos con una menor cantidad de profetas genuinos y con el ascenso del episcopado. De la Didaché se desprende que la decadencia del profetismo no se debe a un mayor intento de control sino que está vinculada a un descenso de la expectativa apocalíptica. Es decir, no esta relacionada a un dispositivo explícito de control sino que en principio habría una menor vocación profética.

Otro texto sumamente importante en el que aparece el discernimiento de espíritus es el del Pastor de Hermas (90-130dc.). Allí el autor hace referencia a la continuidad de los profetas pero estos aparecen ocupando un rol marginal ya que no forman parte de la estructura del gobierno eclesiástico. Es decir, en este texto podemos observar como la autoridad carismática es desplazada por la autoridad institucional aunque no eliminada. El Pastor de Hermas también plantea criterios de discernimiento vinculados al comportamiento como así también criterios doctrinales. Una cuestión interesante en este texto es que se proponen criterios interiores de índole subjetiva para discernir.

Campagne ${ }^{10}$ destaca que uno de los mayores desafíos doctrinales que va a atravesar la iglesia primitiva durante el primer milenio va a ser la herejía montanista

\footnotetext{
${ }^{8}$ Dicha temática es analizada a lo largo de la obra de Parker 1996.

${ }^{9}$ Campagne 2014, 23.

${ }^{10}$ Campagne 2014, 24-25.
} 
(156dc). Dicho movimiento, liderado por Montano va a anunciar una nueva era del mundo y de la Iglesia basada en una presencia extraordinaria del Espíritu Santo. Dicha proclamación como así también el rol central que este movimiento confería al profetismo femenino y los raptos extáticos, llevó a un avivamiento de las ideas sobre el fin del mundo. Ello implicó un desafío a la autoridad eclesiástica, la cual evaluó los raptos extáticos montanistas como ajenos a la tradición del profetismo bíblico y por tanto sospechosos de tener un origen diabólico. Por otro lado, este movimiento será un punto de inflexión ya que si hasta el momento el ethos profético había coexistido con la institución eclesial, con el montanismo se iba a proclamar como superior. Esto tendrá como resultado una contra reacción institucional ${ }^{11}$ y el fin de la coexistencia pacífica entre la religiosidad carismática y la institución eclesial.

Para el periodo inmediatamente posterior al surgimiento de la herejía montanista debemos mencionar los escritos del teólogo Orígenes (185-254dc.). Dichos escritos van a ser producidos en un contexto de la lucha contra el montanismo y bajo los intentos por parte de la institución eclesial de controlar el carisma. A pesar de ello, Orígenes va a priorizar la dimensión subjetiva como criterio de discernimiento de espíritus. Además, va a señalar que el discernimiento requiere de la gracia divina por lo que no hay posibilidad de hacer una ciencia puramente humana del discernimiento de espíritus.

Desde finales del siglo III y durante el siglo IV, los Padres del Desierto van a ir desarrollando el concepto del discernimiento de espíritus en una forma que acompañará el proceso de desarrollo de la experiencia monástica. Como señala Campagne ${ }^{12}$, en la primera época del monacato del desierto, especialmente entre los eremitas, los demonios son considerados entidades externas objetivas. El eremita, como atleta de Cristo, sale a buscarlos en sus refugios de las tierras salvajes y los enfrenta allí. En ese período el discernimiento de espíritus es un carisma extraordinario otorgado por Dios a estos santos atletas de la fe, que les permite autodiscernir para evitar los engaños del demonio. Progresivamente, con el avance del monacato cenobítico que busca regular los extremos de la experiencia monástica, los demonios irán adquiriendo un carácter metafórico, como representaciones de los pecados y malos pensamientos. En consonancia con ello el discernimiento de espíritus pasará a ser, progresivamente, un arte de la dirección espiritual, una virtud vinculada a la prudencia, por la que los abades dirigen a los monjes en el camino del progreso espiritual.

Este proceso de «domesticación» de los demonios (paralelo al de la domesticación de las experiencias carismáticas) que ocurre en el seno del monacato, hará desaparecer progresivamente de la escena teológica al discernimiento de espíritus. Ahora reducido a mero «discernimiento» a secas e identificado con la prudencia que permite evitar las tentaciones y el pecado, desaparecerá por un tiempo del debate cristiano.

Pero, a partir del siglo XII, durante la baja edad media, una nueva explosión de experiencias místicas, originada en el norte de Europa, hará retornar a la escena a

11 Este tema es abordado en el libro de Caciola 2003.

12 Campagne 2014, 25-27. 
los demonios y con ellos volverá la preocupación por el discernimiento de espíritus. Si bien en una primera etapa, la jerarquía de la iglesia tendrá fascinación, asombro y respeto por las místicas, hacia el segundo cuarto del siglo XIII esta especie de «luna de miel» comienza a transformarse en desconfianza ${ }^{13}$. Esto se debe a que las experiencias de las místicas femeninas van a impulsar una nueva subjetividad religiosa que plantea una relación de carácter amoroso, intransferible e inefable con la divinidad. Dado que las místicas femeninas van a priorizar la afectividad como vía superior de conocimiento y que van a utilizar el autodiscernimiento de espíritus para legitimar sus experiencias religiosas, la jerarquía de la iglesia volverá a discutir el status del discernimiento de espíritus intentando someter a crítica el concepto de autodiscernimiento y el rol de la afectividad en él, buscando progresivamente dejar en manos de la jerarquía eclesiástica la discriminación de los espíritus entendida como una ciencia humana. La preocupación por establecer los límites de lo sagrado y el problema de la autoridad sumado al conflicto que atravesaba la institución eclesiástica producto del Gran Cisma son algunos de los factores principales que conducirán a la aparición de un género específico de textos, abocado a establecer criterios para probar los espíritus ${ }^{14}$. En este contexto es que podemos ubicar los tratados de Jean Gerson.

Preocupado por la explosión del misticismo y por la necesidad de disciplinar las distintas formas de religiosidad carismática, Jean Gerson va a plantear la necesidad de poner a prueba a los espíritus. Para ello, va a proponer un método basado en la metáfora del examen que se le hace a una moneda para determinar si es verdadera o falsa. El autor propone una serie de virtudes que debe tener el carismático para que sus visiones sean consideradas genuinas: humildad (peso de la moneda), discreción (maleabilidad), paciencia (durabilidad), verdad (forma) y caridad (color) ${ }^{15}$. Para Gerson, serán los teólogos los agentes encargados de discernir y el tipo de conocimiento al que podrán aspirar será conjetural.

En otro de sus tratados, Gerson realiza una clasificación de tipos de discernimiento de espíritus: discernimiento académico entendido como el arte humano conjetural, de ethos probabilístico; el discernimiento empírico vinculado a las sensaciones interiores que son intransferibles; el discernimiento oficial entendido como el carisma paulino; y el discernimiento experiencial. Para Gerson, solo el discernimiento empírico y el oficial son sobrenaturales por lo tanto ambos son infalibles. Una cuestión interesante de la propuesta de Gerson vinculada a sus intentos por llevar a cabo una institucionalización del carisma es que si bien el discernimiento empírico solo puede discernir experiencias propias, el oficial podrá discernir tanto propias como las de terceros. Además, este tipo de discernimiento será concedido por la divinidad a aquellos que cumplan funciones de autoridad dentro de la iglesia, es decir ex officio. En este sentido, desde la perspectiva de Gerson el candidato perfecto para poner a

\footnotetext{
${ }^{13}$ McGinn 2004, 209.

${ }^{14}$ Rubin 2001, 103.

${ }^{15}$ Campagne 2014, 52-58.
} 
prueba a los espíritus será el teólogo con experiencia mística o el místico con estudios teológicos ${ }^{16}$.

Este breve esbozo que realizamos siguiendo el análisis de Campagne sobre la historia social del discernimiento de espíritus nos permite observar la variedad de concepciones que se desarrollaron a lo largo del tiempo sobre este dispositivo teológico. Dicha variedad de concepciones dio lugar a distintas maneras de entender el control del acceso al carisma. A continuación, nos abocaremos a examinar un caso particular de cristianismo aborigen: el evangelio entre los mocoví. Nuestro análisis nos permitirá explorar el concepto de discernimiento de espíritus en el contexto de las iglesias evangélicas aborígenes. Además, nos permitirá incorporar el rol desempeñado por los agentes misioneros y los intentos de regulación que estos despliegan. Como hemos discutido en esta sección, el discernimiento de espíritus como dispositivo de regulación se encuentra profundamente imbricado con las concepciones de poder y las estructuras de autoridad. Veremos que en el contexto de las iglesias mocoví evangélicas, se encuentran las estructuras de autoridad y concepciones de poder de las iglesias misioneras, las propias de la sociedad mocoví y las de la sociedad nacional envolvente. La compleja situación que describimos, es característica de las iglesias en contextos coloniales y post-coloniales. Esta variedad de concepciones da lugar a distintas maneras de entender el control del acceso al carisma. Es por ello que la exploración del concepto de discernimiento de espíritus en el contexto de las iglesias evangélicas aborígenes abre el juego a entender los distintos mecanismos de regulación y control del acceso al carisma en estas sociedades.

\section{LOS MOCOVÍ}

Los mocoví (moqoit) habitan la zona sur de la región chaqueña, en la República Argentina ${ }^{17}$. Pertenecen al grupo lingüístico guaycurú junto con los toba, abipón, pilagá, caduveo y mbayá. Tradicionalmente eran grupos cazadores-recolectores que se organizaban en bandas nómades exógamas, generalmente bilaterales y uxorilocales $^{18}$. Durante la colonia este grupo se vio obligado a desplazarse hacia el sur y al este: Santa Fe y Corrientes, zonas originariamente no mocoví ${ }^{19}$. En ese mismo período se produjo una profundización del proceso de evangelización católica ya que los jesuitas lograron instalar una serie de misiones y continuaron sus labores hasta su expulsión en 1767. La presencia de los jesuitas fue sustituida por la acción de mercedarios y franciscanos. Dicha presencia fue mucho más irregular que la de los jesuitas.

\footnotetext{
${ }^{16}$ Campagne 2014, 62-74.

17 Actualmente el número de mocoví asciende a 12.145 personas entre las provincias de Chaco y Santa Fe, y 3.692 personas en el resto del país. Estos datos han sido relevados por el INDEC 2004-2005.

18 Braunstein 1983, 8-22.

19 Susnik 1972, 18s.
} 
No obstante, se desarrolló un catolicismo moqoit, en el que el culto a los santos y vírgenes cobró particular importancia ${ }^{20}$.

Como señala López ${ }^{21}$, a fines del siglo XIX y principios del siglo XX el avance de colonos hacia el territorio chaqueño desde Santa Fe provocó el retorno de muchos mocoví a zonas del sur de la actual provincia del Chaco. Con el transcurso del tiempo y de manera progresiva, los mocoví se fueron estableciendo en comunidades sedentarias y, estacionalmente, comenzaron a trabajar en las cosechas y realizar labores temporales en establecimientos agrícolas y obrajes. La comunidad mocoví en la que realizamos nuestro trabajo etnográfico se encuentra a unos $22 \mathrm{~km}$ de la ciudad de Charata (Chaco).

Como mencionamos en la introducción, varias denominaciones evangélicas llegaron al Chaco argentino en la primera mitad del siglo $\mathrm{XX}^{22}$. Su interacción con los aborígenes de la región -fundamentalmente toba, mocoví, pilagá y wichí- dio origen al movimiento del evangelio, actualmente de importancia fundamental en la dinámica social de dichos grupos. Un evento sumamente importante en la conformación del movimiento del evangelio esta vinculado con el hecho de que para 1950, debido a diversos conflictos entre líderes distintas congregaciones, la Mennonite Board of Mission -que había fundado la misión Nam Cum en Chaco en 1947-decide contratar una pareja de antropólogos. Estos sugirieron a los menonitas disolver la misión tradicional y acompañar a los aborígenes en su propia elaboración del cristianismo ${ }^{23}$. A partir de este cambio, los misioneros menonitas se autodesignan Obreros Fraternales e inician la traducción de las Escrituras al idioma nativo. Además, comienzan a promover la eliminación de los vínculos denominacionales y colaboran en la fundación y el reconocimiento por parte del Estado argentino de la primera iglesia aborigen del país: la Iglesia Evangélica Unida (IEU) ${ }^{24}$.

Los primeros contactos de los mocoví con el evangelio se dieron en las comunidades del Chaco, cobrando importancia durante los años '70, a través de los vínculos de algunos mocoví con diversas comunidades toba y su participación en cultos y otros eventos organizados por sus iglesias ${ }^{25}$. Posteriormente, visitas relámpago de misioneros toba a comunidades moqoit reforzaron dichas experiencias. Las conversiones entre los mocoví siguieron las relaciones de parentesco. En este sentido, la conversión de un jefe de familia o el líder de un grupo de familias emparentadas solía generar la conversión de su grupo de parientes, la fundación de un lugar de

\footnotetext{
${ }^{20}$ La importancia que ha tenido el catolicismo en el contexto mocoví ha sido trabajado profundamente en la tesis doctoral de López 2009.

21 López 2009, 18 s.

22 Entre los misioneros que llegaron al Chaco hay misioneros de diversas denominaciones desde Anglicanos a Menonitas pasando por los Hermanos Libres. Entre estos grupos la influencia del pentecostalismo fue especialmente importante.

23 Reyburn 1954, 71-78.

${ }^{24}$ Para profundizar sobre las tareas que desempeñaron los Obreros Fraternales Menonitas ver: Buckwalter y Buckwalter 2009, 194-198.

25 Altman 2011, 129.
} 
culto y el establecimiento de una red de vínculos con las iglesias evangélicas toba y/o criollas $^{26}$. En la actualidad, la comunidad estudiada cuenta con cinco cultos ${ }^{27}$, que suelen afiliarse o desafiliarse a la Iglesia Evangélica Unida u otras denominaciones evangélicas. Cada uno de estos cultos corresponde a un grupo de parientes, cuyo líder político suele ser el pastor. Estos pastores suelen edificar en su terreno la iglesia en donde se congrega el culto.

Desde sus orígenes, el evangelio configuró y configura dentro del ámbito de las iglesias un espacio de encuentro entre dos habitus ${ }^{28}$ distintos: un habitus protestantepentecostal y un habitus mocoví preexistente a la llegada de los misioneros ${ }^{29}$. Este encuentro de habitus se refleja en la estructura social de las iglesias; en sus concepciones sobre los vínculos con las potencias no-humanas; la gestión de salud y enfermedad; y la experiencia del culto. En tanto que estas dimensiones estructuran al discernimiento entendido como un dispositivo de control del acceso al carisma, el encuentro de habitus será crucial para entender las formas que este toma entre los aborígenes evangélicos del Chaco.

\section{DISCERNIMIENTO DE ESPÍRITUS Y ESTRUCTURA SOCIAL EN LAS IGLESIAS EVANGÉLICAS ABORÍGENES DEL CHACO}

Las iglesias evangélicas aborígenes del Chaco tienen una estructura social cuya unidad son pequeños cultos relacionados mediante alianzas laxas y fluctuantes en los cuales la construcción de liderazgo tiene un impacto fundamental.

Ya mencionamos que la conversión al evangelio siguió líneas de parentesco de modo que un culto evangélico aborigen tiende a agrupar a miembros de una misma

\footnotetext{
${ }^{26}$ Altman 2011, 131-134.

${ }^{27}$ El término «culto» es una expresión vernácula con la que se designa la unidad social mínima de la experiencia evangélica moqoit. Un culto está conformado por un pastor, un pequeño espacio para la realización de «los cultos» - es decir las celebraciones religiosas- que puede ser una pequeña construcción, un toldo en el patio de tierra o simplemente un conjunto de bancos o sillas en dicho patio -en general ubicado en el terreno del pastor-, y un pequeño conjunto de miembros. Los miembros de un culto son el grupo de parientes que conforman la red de alianzas del pastor en cuestión. De modo que el pastor es líder tanto político como espiritual de esta unidad social, lo cual reproduce las prácticas previas a la presencia evangélica. Respecto a la categoría «denominación», esta sigue en general el uso habitual en el mundo evangélico y puede asimilarse al empleo en dicho contexto del término «iglesia». Los cultos individuales suelen afiliarse a una denominación, las cuales en la práctica funcionan como confederaciones laxas de cultos, con una supervisión bastante superficial en términos dogmáticos y de prácticas rituales. Pero las denominaciones tienen un rol muy importante en términos de acceso a recursos externos (legitimación ante el Estado y el mundo criollo, acceso a financiamiento externo, acceso a redes de vínculos en el mundo no aborigen) y de alianzas políticas entre diferentes líderes y sus grupos. En ese sentido las denominaciones parecen cumplir un rol sociológico análogo al de las antiguas tribus, como las máximas instancias de alianza política y comunidad histórica, sometidas a permanentes procesos de fisión y fusión. Incluso al igual que las antiguas tribus suelen incluir grupos de diversa procedencia étnica.

28 Bourdieu 1972, 175-179.

${ }^{29}$ Debemos destacar que este habitus mocoví al que hacemos referencia no sólo estaba configurado por pautas previas a la llegada de los europeos sino también por la extensa experiencia de misionalización católica en la región.
} 
familia extensa. Esto se vio reforzado por el hecho de que las iglesias evangélicas que misionaron en el territorio chaqueño traían una estructura de origen basada en el modelo congregacional que pone en primer plano a la pequeña congregación local. De este modo, en el caso chaqueño parientes y congregados resultaron ser casi sinónimos. En sus países de origen las congregaciones evangélicas han seguido complejos procesos de fusión y fisión. Las fusiones, alimentadas por el anhelo cristiano de la unidad universal, se concretan en la forma de confederaciones o federaciones de cultos. Las fisiones derivadas de disputas teológicas, morales, disciplinarias y de liderazgo se traducen en la ruptura de estas unidades mayores. De este modo, históricamente se ha dado una permanente creación y destrucción de unidades de orden superior a la congregación local. Entre los aborígenes chaqueños, cazadores recolectores, la estructura social se funda en las familias extensas que construyen alianzas fluctuantes mediante el matrimonio. Dichas alianzas son inestables y están continuamente reconfigurándose. La convergencia de estos dos modos de organización llevó a que la dinámica de las iglesias evangélicas chaqueñas se convirtiera en un canal de legitimación en el contexto colonial y post-colonial para las disputas tradicionales de la estructura de parentesco aborigen. De ese modo, los cultos evangélicos y su afiliación a distintas denominaciones son simultáneamente redes de familias extensas aliadas por parentesco. En este contexto, las disputas por el liderazgo (simultáneamente religioso y político) son un elemento fundamental.

La aparición de las iglesias evangélicas entre los aborígenes chaqueños significó tanto continuidades como rupturas para las dinámicas previas de liderazgo.

Tradicionalmente, la autoridad de un líder mocoví residía en su grupo de parientes más cercanos y en las alianzas con otros por matrimonios. Con la colonización del Chaco, los líderes se convirtieron en mediadores entre los grupos de familias que lideraban y los patrones criollos que buscaban mano de obra para sus establecimientos agrícolas y obrajes. Este nuevo rol implicó la adquisición de habilidades como el aprendizaje del castellano y la capacidad para negociar las condiciones de trabajo con los patrones ${ }^{30}$.

Como señala Ceriani Cernadas para el caso toba ${ }^{31}$, entre los mocoví la emergencia de las iglesias evangélicas también ofrecieron un nuevo espacio de relaciones donde construir autoridad hacia el interior del grupo y en articulación con la sociedad «blanca». El evangelio aportaba formas de acceso a la legitimidad simbólica, a recursos económicos y a bienes por distribuir, disponibles para las nuevas generaciones que tenían expectativas de acceso al liderazgo por fuera de los tradicionales «linajes de prestigio» $\mathrm{y}$ «linajes shamánicos» ${ }^{32}$. Esto también se vio favorecido por el hecho de que el evangelio y su estructura de cultos bastante autónomos asociados en federaciones laxas se conjugó con una coyuntura local: el fin del sistema de enganches para el trabajo en gran escala en el campo donde los caciques tradicionales eran el vínculo

\footnotetext{
${ }^{30}$ López 2009, 160.

31 Ceriani Cernadas 2009, 8.

32 López 2009, 179.
} 
con los patrones, la disminución de la mano de obra y el tamaño de las cuadrillas, más el mayor contacto con los criollos y un mayor acceso a los bienes. Como señala Wright $^{33}$, con el objetivo de disputar posiciones de poder, los nuevos líderes devenidos pastores no sólo debieron incorporar el poder espiritual, la palabra iluminada y la fuerza física que solían tener los antiguos caciques sino también, nuevas herramientas de negociación política como el conocimiento del castellano y de la política criolla. Debido a que los jóvenes eran los que generalmente estaban más capacitados esto también influyó en la reestructuración del liderazgo y provocó una reconfiguración simbólica ya que a través de las jerarquías de las iglesias evangélicas aquellos jóvenes aspirantes a líderes podrán acceder a posiciones de poder.

A pesar de estas transformaciones en los esquemas tradicionales de liderazgo, la conformación de la estructura institucional del evangelio entre los mocoví reforzará algunos elementos preexistentes a la llegada de los misioneros. Así por ejemplo, la estructura de las iglesias estará signada por la lógica de las relaciones de parentesco y los particulares modelos de pertenencia asociados a ella. Esto es posible por la afinidad del carácter congregacional de las iglesias y las dinámicas de fisión y fusión propias de las lógicas de parentesco.

En este panorama, el surgimiento de la Iglesia Evangélica Unida, impulsada por los Obreros Fraternales Menonitas, representa un hito importante. Su objetivo fundacional fue, por una parte, darles a las iglesias evangélicas aborígenes la mayor autonomía posible respecto a los misioneros extranjeros dando lugar a un verdadero evangelio aborigen. Por otra parte, buscaba establecer una unidad definitiva que agrupara a todos los cultos evangélicos aborígenes del Chaco. Esta utopía de abolir las dinámicas de fusión y fisión propias tanto de las sociedades chaqueñas como del campo evangélico dará origen a algunas de las características más singulares de la IEU.

El discernimiento de espíritus, como dispositivo político en la vida de las iglesias aborígenes chaqueñas, adquiere características que están vinculadas a las tensiones propias de la estructura de organización de las mismas.

Por una parte, la dinámica cotidiana en el movimiento evangélico de los aborígenes chaqueños está centrada en las pequeñas congregaciones locales y las interacciones entre congregaciones vecinas. Es cierto que los líderes de las diversas congregaciones suelen estar interesados en construir alianzas a nivel regional tanto con aborígenes como con criollos, buscando así reforzar su prestigio, autoridad e influencia. Pero la estructura social de estas congregaciones posee mecanismos de control informal que buscan evitar la excesiva acumulación de poder o prestigio. Estos mecanismos son propios de las dinámicas de los aborígenes chaqueños y están ligados a una ética reciprocitaria para la cual toda acumulación es sospechosa y sancionada por el rumor o las acusaciones de brujería. Este carácter eminentemente local lleva a que el discernimiento sea una cuestión que acontece esencialmente en el transcurso de las interacciones personales, cara a cara entre los miembros de una misma congregación.

33 Wright 2008b, 140. 
Interacciones que se caracterizan por una estructura relativamente horizontal propia de una construcción fluctuante y contextual del liderazgo. Por ello mismo, el discernimiento se encuentra ligado a performance ${ }^{34}$ rituales e interacciones cotidianas. Estas características pueden observarse en los comentarios que un creyente mocoví -al que llamaremos Simón-nos hizo durante una entrevista cuando le consultamos cómo hacen los creyentes para discernir los distintos espíritus, él nos respondió:

S.: - Y se siente cuando es parte de Dios, la iglesia siente.

A.: - ¿La comunidad junta? ¿Y como se sentiría?

S.: -Se siente, en la iglesia se siente cuando uno habla en lengua y no es parte de

Dios se siente. Si es de parte de Dios se siente, todo se siente como le puedo decir se siente un escalofrío, una emoción, tiene ese gozo dentro digamos.

A.: $-i$ Se siente como que estas emocionado?

S.: -Claro. Se siente cuando es parte de Dios.

A.: $-i Y$ cuando no?

S.: $-Y$ la Biblia dice que uno tiene que examinarle si es parte de Dios, parte del Espíritu, si es de Dios o no porque son dos espíritus: el verdadero y el engañador.

A.: $-i$ Y cómo..?

S.: -Desde el comienzo dice que algunos fueron profetas falsos y ahora en nuestro tiempo ocurre pero espiritualmente.

A.: $-i$ Y eso cómo lo examinas?

S.: -Cuando no es parte de Dios la iglesia no siente nada. Si hay una profecía así.

Cuando la iglesia es tocada por el Espíritu no puede detenerse ese gozo.

En este fragmento de la entrevista podemos observar como a partir de la interacción cara a cara se construye un consenso entre los participantes del culto, que es pensado como «la voluntad» de la propia iglesia, expresada como un sentimiento de la comunidad de fieles que permite discernir ${ }^{35}$. En este ejemplo podemos observar una de las caras del discernimiento en estos grupos, cuyas características se vinculan a la escala local de las unidades sociales en cuestión y a una dinámica social basada en el parentesco y en interacciones cara a cara. Así como también a los modos particulares de la memoria, la disputa y el consenso propios de sociedades predominantemente orales ${ }^{36}$.

\footnotetext{
${ }^{34}$ Usamos el termino performance -en línea con los usos de Víctor Turner y Thomas Csordas- para referirnos a acciones en las que la puesta en escena del cuerpo juega un rol fundamental. No son simplemente representaciones de valores sociales y culturales preexistentes sino que, como espacio en el que la sociedad se piensa a sí misma, tienen el potencial tanto de consolidarlos como de modificarlos. Este tema ha sido ampliamente abordado en: Citro 2009, 29-36.

35 Debemos señalar que esto no implica que el significado otorgado a estas experiencias emotivas se clausure en una primera interpretación inmediata, sino que la situación volverá a ser traída a la memoria, recreada o reevaluada a partir de ciertas formas discursivas prototípicas (por ejemplo el testimonio) que son puestas en juego en nuevas interacciones.

${ }^{36}$ Estos temas son centrales a lo largo de la obra de Goody 1996 y Ong 1993.
} 
Por otra parte, en relación con el proyecto de unidad del evangelio aborigen impulsado por los Obreros Fraternales Menonitas, observamos una búsqueda por normar el discernimiento y su ejercicio. Dado el carácter de dispositivo de control del acceso al carisma que tienen el discernimiento de espíritus, no es extraño que el impulso dado por los misioneros no aborígenes a la IEU como institución que busca unificar a los aborígenes evangélicos de la región chaqueña y que utiliza la palabra escrita como uno de los instrumentos centrales para lograr este objetivo, involucre intentos por regular el discernimiento. Un ejemplo de ello es el «Manual para ministros en las Iglesias evangélicas indígenas del Gran Chaco de la Argentina» editado en $2006^{37}$. El mismo tiene una introducción en la que se presenta a dicho material como una colaboración entre pastores y obreros aborígenes y el Equipo Menonita que explícitamente declara que:

(...) no pretende establecer normas nuevas ni dictar prácticas obligatorias para las iglesias indígenas evangélicas. Tampoco pretende presentar la práctica de las iglesias no-indígenas como el modelo más deseable. Sino el propósito es de respetar la formas y prácticas ya establecidas como costumbres por las iglesias indígenas ${ }^{38}$.

Sin embargo, al analizar el contenido de dicho material observamos que las opiniones, consejos o modelos de ceremonias desarrollados en el mismo utilizan el modo verbal imperativo. Así por ejemplo, aparecen frases como: «[...] todos los ministerios de la iglesia, también los dirigentes de alabanza deben someterse a los pastores locales ${ }^{39}$. De este modo, si bien el Manual pretende presentarse como flexible, cristaliza una selección de principios generales con el fin de lograr una uniformidad legitimada por la escritura, tecnología de gran prestigio para los aborígenes chaqueños.

Algunos de los temas que aborda el «Manual para ministros en las Iglesias evangélicas indígenas del Gran Chaco de la Argentina» son: la iglesia indígena, ministerios en las iglesias indígenas, el culto, relaciones entre iglesias, etc. Una cuestión sumamente interesante es que en el capítulo «La Iglesia Indígena» cada cargo en la iglesia esta asociado a un don especial y al pastor se le asigna el don del discernimiento de espíritus:

Hay otros poderes espirituales que pueden estar mezclados en las expresiones de alabanza y gozo. Los pastores deben tener discernimiento. No deben prohibir el movimiento verdadero del Espíritu de Dios, pero no conviene permitir actividad de los poderes malos ${ }^{40}$.

Al vincular cada puesto a un don, este manual intenta homogenizar y normar las prácticas que acontecen en el contexto de las iglesias aborígenes. Además, al asig-

\footnotetext{
${ }^{37}$ Equipo Menonita 2006.

38 Equipo Menonita 2006, 2.

39 Equipo Menonita 2006, 13.

40 Equipo Menonita 2006, 101.
} 
narle al pastor el don de discernimiento lo transforma en un agente de regulación del acceso al carisma. El Manual no surge como fruto espontáneo de la dinámica de las congregaciones locales, sino que es una inquietud vinculada a los misioneros y su búsqueda de construir una unidad evangélica aborigen. Lo que nos interesa destacar es que así como existen mecanismos sociales entre los aborígenes chaqueños para evitar que los líderes acumulen demasiado poder, la acción de los misioneros apunta en la dirección opuesta. De hecho, no es casualidad que la mayor parte de las iglesias misioneras se dedique activamente a la formación de líderes. De este modo, al diseñar mecanismos para potenciar líderes, por ejemplo al asignarle a los pastores el don de discernimiento, los misioneros contrarrestan los mecanismos centrífugos que en las sociedades aborígenes chaqueñas balancean la formación de alianzas.

Vemos por tanto que la acción misionera busca reforzar la unidad en el campo evangélico aborigen, no solo mediante el impulso de una única iglesia evangélica aborigen, no casualmente llamada Iglesia Evangélica Unida, sino también mediante la elaboración de materiales como el «Manual para ministros», y la tipificación y regulación de los cargos en las iglesias y el establecimiento de un cuerpo más estable de especialistas.

A lo largo de este apartado hemos visto como el discernimiento de espíritus es un dispositivo clave en la regulación del acceso al carisma y por ello está fuertemente vinculado a las dinámicas de organización social de las iglesias. El caso de las iglesias aborígenes chaqueñas muestra como las tensiones entre las concepciones de organización eclesial de misioneros no aborígenes y la de creyentes aborígenes se traduce en una tensión entre dos formas diferentes de concebir el discernimiento de espíritus.

En los siguientes apartados, centrándonos en nuestra experiencia etnográfica en comunidades mocoví, discutiremos la forma en que esta tensión se manifiesta en algunos ámbitos clave: la relación entre humanos y no-humanos, la gestión de la salud y la enfermedad, y la experiencia del culto.

\section{HUMANOS Y NO-HUMANOS}

Así como los aborígenes chaqueños conciben tradicionalmente a las sociedades humanas como basadas en alianzas fluctuantes y múltiples entre familias extensas, piensan a los seres potentes no-humanos como parte de sociedades estructuradas bajo el mismo principio. De hecho, las relaciones con lo numinoso serán una extensión de las lógicas de alianza entre parientes.

Desde esta perspectiva, el mundo esta gobernado por diversas entidades no-humanas que en castellano suelen llamarse poderosos. Estos seres se comportan como «dueños» de regiones, ámbitos o especies a los que protegen y sobre los que pueden conceder su acceso o denegarlo. Los poderosos son pensados como seres excesivos y peligrosos que pueden tener múltiples «regímenes corporales» ${ }^{41}$ como consecuencia

${ }^{41}$ Tola 2009, 46-47. 
de su superabundancia de potencia. Debido a que son considerados como los responsables de la abundancia y la fecundidad, son entidades con las que es imprescindible vincularse ${ }^{42}$. El modo de regular dichas interacciones es a través del establecimiento de pactos. Esta manera de tender un puente con el mundo no-humano implica un reconocimiento de la asimetría de la relación entre estos y los humanos. Pero si bien estos últimos están dotados de una menor jerarquía a su vez poseen la cantidad suficiente de poder como para negociar con los poderosos.

Los diversos emprendimientos cristianos que arribaron a la zona (tanto la presencia católica como las diferentes denominaciones evangélicas) se articularon de manera compleja con la experiencia shamánica. Así por ejemplo, el catolicismo (particularmente el catolicismo popular) aportó por ejemplo el culto a los santos, la Virgen y sus imágenes, las peregrinaciones, la intercesión de los difuntos y las fiestas patronales -que se entroncan en las tradiciones propias del catolicismo barroco ${ }^{43}$, de gran impacto en el proceso evangelizador de América- ofreciendo mediante estas instancias importantes espacios de resignificación simbólica ${ }^{44}$. Si bien la llegada del evangelio clausuró estos espacios, abrió otros nuevos al horizonte shamánico. Como señala Miller ${ }^{45}$, las experiencias extáticas y la comunicación directa y personal con lo sobrenatural proporcionaron importantes puntos de contacto entre la experiencia shamánica y el pentecostalismo. Así por ejemplo, la obtención de dones carismáticos del Espíritu Santo, las «visitas» del mismo a los creyentes, e incluso las posesiones demoníacas, son pensadas en términos de vínculos y pactos con entidades poderosas, de forma análoga a los modos característicos de obtención de poder en contextos shamánicos.

Por ello el discernimiento de espíritus atraviesa todos los aspectos de la vida cotidiana. Esto está profundamente vinculado con el hecho de que para los mocoví, como así también otros grupos aborígenes chaqueños, el mundo en el que viven es un mundo socializado que está habitado por distintas sociedades, tanto humanas como no-humanas, con las que hay que interactuar y pactar para obtener algún tipo de beneficio, conocimiento o poder. Así por ejemplo, la interpretación de señales o sueños, que son pensados por los mocoví como signos que señalan una intención, es esencial en el proceso de conocimiento del mundo, ya que en un universo socializado es fundamental comprender qué es lo que los otros seres con los que se convive quieren comunicar.

La acción misionera inauguró con sus propios supuestos implícitos la idea de un espacio de lo natural opuesto al espacio de lo sobrenatural que en las categorías y en la experiencia mocoví no tenían equivalentes. De este modo, en el discurso de los misioneros y en sus prácticas aparece de manera implícita la concepción de una esfera bien delimitada de la naturaleza entendida como neutra, en la que no existen

\footnotetext{
42 López 2009, 200.

43 Para profundizar sobre este tema: Gruzinski 2007.

44 Para más información sobre la presencia católica entre los mocoví ver: López 2009.

45 Miller 1979, 115.
} 
presencias misteriosas ni se requiere la intervención divina. Esta esfera estará claramente separada del ámbito de lo sagrado, espacio que estará mediado por especialistas. Así por ejemplo, aunque los misioneros menonitas no van a adjudicar las experiencias del Espíritu de los mocoví a causas médicas o psico-fisiológicas, van a tender a construir con sus prácticas cotidianas la idea de que existe una dimensión «puramente natural» del mundo, una esfera secular, donde los agentes no-humanos no tienen nada que hacer. Una cuestión interesante para destacar es que los propios misioneros menonitas van a reflexionar en torno al impacto de su presencia entre los aborígenes chaqueños y sobre lo que denominaron «efectos inesperado de las misiones protestantes entre los aborígenes del Gran Chaco ${ }^{46}$. Uno de esos efectos que el misionero Elmer Miller va a mencionar es el proceso de «desencantamiento» del mundo ${ }^{47}$.

Así por ejemplo, Miller señala las diferencias en lo referente a las concepciones sobre el proceso de aprendizaje, que desde la perspectiva aborigen se llevaba a cabo a través de sueños ${ }^{48}$, visiones o a través de la comunicación con seres no-humanos, mientras que los misioneros harán énfasis en la concentración y apelarán a las capacidades cognitivas «naturales» de los seres humanos. Debido a estas cuestiones es que Miller caracteriza a los misioneros como «agentes de secularización» ya que mediante sus prácticas (círculos bíblicos, prédicas y material escrito) y el intento de normar las prácticas de los propios aborígenes van a llevar a cabo un proceso de creación y delimitación del espacio de lo sagrado. Esto también implicará acotar las áreas de la vida donde el discernimiento de espíritus tendría importancia.

La distinción que los misioneros menonitas llevarán a cabo entre el mundo natural y el sobrenatural es en sí misma revolucionaria para las concepciones mocoví que en general asumen que los no-humanos puede estar presente hasta en las actividades más cotidianas. De hecho, cualquier habilidad especial para algo implica algún tipo de pacto con un poderoso.

La gestión de la salud y la enfermedad constituyen un campo privilegiado en el que podemos ver como se despliegan las diversas concepciones del discernimiento de espíritu que coexisten al interior del evangelio mocoví.

\section{SALUD Y ENFERMEDAD}

Para los creyentes evangélicos mocoví, las enfermedades son conceptualizadas como una pérdida de potencia cuyas causas en última instancia derivan de la acción de seres no-humanos, que los creyentes evangélicos identificaran como Dios o demonios. Estos seres pueden actuar directamente, ofendidos por alguna conducta humana, o pueden entrar en acción convocados por algún enemigo humano del afec-

\footnotetext{
46 Miller 1977, 5.

47 Miller 1977, 4-5.

${ }^{48}$ Para profundizar sobre el rol central de los sueños en la experiencia guaycurú ver: Wright $2008 \mathrm{a}$.
} 
tado. La salud, tal como ocurría en el contexto shamánico ${ }^{49}$, no es pensada como algo dado sino que se trata de una condición que requiere del correcto vínculo social con el entorno humano y no-humano. Por lo tanto para reestablecerla es necesario que se puedan restaurar las correctas relaciones con lo numinoso ${ }^{50}$, y para ello es imprescindible reconocer al agente que causó dicho daño ${ }^{51}$, lo cual puede lograrse a través del discernimiento de espíritus, tal como aparece en este relato con el retorno al evangelio por parte de una mujer:

(...) ella siguió en el evangelio después quiso dejar por cosas que pasan vio y quiso dejar a Dios y se enfermó muy mal, casi murió y en ese estado, en agonía, de muerte ya ahí le habló el Señor, le dijo: 'yo te devolveré la vida pero si vos me haces caso', así le dijo esa voz, el mismo Espíritu Santo, el Espíritu de Dios le habló a ella. Dijo que 'sí, te voy a obedecer ahora', 'aunque tenes que pasar los momentos de desprecio, de calumnia, de todo, vos tenes que soportar porque yo te voy a devolver la vida’ y le dijo que sí. Y se salvó.

Es debido a esto que se vuelve de vital importancia discernir que entidades están involucradas en los distintos acontecimientos de la vida cotidiana del creyente. El pacto con el Espíritu Santo es la fuente de poder no-humano a la que recurrirán los mocoví evangélicos para llevar adelante dicha tarea. En principio, y a diferencia de lo que ocurre en el contexto shamánico ${ }^{52}$, el pacto con el Espíritu Santo implica renunciar a tener pactos con otras entidades. Sin embargo, ésta es una cuestión permanentemente debatida por los mocoví evangélicos, situación que se refleja en el interés permanente que manifiestan por los pactos que mocoví no evangélicos establecen con otras entidades poderosas y los beneficios que obtienen de los mismos.

El testimonio de una creyente, obtenido durante nuestro trabajo de campo, nos servirá para ilustrar el rol que juegan en la experiencia del discernimiento las emociones y sensaciones del creyente:

Se conoce, se sabe por eso dice Dios, Dios te dirá a tu Espíritu Santo usted va a saber lo que es de Dios o lo que no es de Dios porque ese que está adentro tuyo hace el pacto que no es de Dios porque hay cosas que solo son iguales, las obras que

\footnotetext{
49 Los testimonios de mocoví evangélicos sobre los estados de salud y enfermedad muestran claramente que los discursos shamánicos son aún en este contexto importantes modelos de referencia. Ambos aluden a una noción de persona conceptualizada como un devenir, poroso y múltiple que atraviesa distintos momentos de corporalidad durante el ciclo vital: nacimiento, enfermedad y muerte. Algo similar ocurre con la relación entre los hombres y su vínculo con lo poderoso. Para profundizar sobre las nociones de persona entre los guaycurú ver: Tola 2012 .

${ }^{50}$ Uno de los autores que más ha trabajado el vínculo entre enfermedad y poder es: Wright 1990.

51 Daño es una categoría emic que hace referencia a una acción intencional cuyo objetivo es atacar (frecuentemente mediante un padecimiento físico o anímico) mediante diversas técnicas que pueden incluir el empleo de seres no-humanos, la manipulación de objetos personales, fluidos corporales, etc.

52 Un shamán puede pactar con diversos poderosos no-humanos, y de hecho en general buscará acumular la mayor cantidad de pactos posibles ya que incrementan su poder.
} 
hace. Por eso dice la Biblia: 'muchos engañadores saldrán en los últimos tiempos que están, que van a ser como igual que el Espíritu de Dios o el Espíritu de Cristo pero no lo son'. ¿Y cómo los tenés que conocer? ¿Como podes conocer un poco? Si no el que está adentro, si usted está bien delante de Dios el Espíritu Santo este conoce el pacto que no es de Dios, no es de Dios, no es de Dios y tenés que hacerle caso al que está adentro, lo que vos sentís de la vida, la persona, eso es. (...) A veces yo digo ¿cómo podemos saber? Porque si nosotros estamos bien delante de Dios, sentimos por dentro que no es de Dios y que me venga a hablar pero adentro tuyo no hace, no hace contacto. Hay algo que vos no lo sentís que no es, que hay algo.

Por otra parte, de modo similar a lo que ocurre en el contexto shamánico ${ }^{53}$, algunos creyentes evangélicos logran establecer con el Espíritu Santo un «mejor acuerdo» que los habilita para realizar el discernimiento de espíritus de forma especialmente eficiente, aunque no exclusiva ${ }^{54}$. Durante nuestro trabajo de campo una creyente mocoví a la que llamaremos Gregoria nos relató un ejemplo de este tipo de situaciones. Su hijo se encontraba enfermo y ella consultó sobre la razón de dicha enfermedad a otra creyente, a la que llamaremos Roberta, que posee el don de discernir las entidades no-humanas involucradas:

G.: - (...) Yo me voy para la casa de la hermana Roberta, un día viernes fue, me fui un viernes. Esa noche oré y yo le dije a ella que le avise el problema de él y que tenía problema en la columna y bueno oró, ¡¿Usted sabe cómo habló?! ¡Ay! parece como si fuese que estaba mi hijo ahí delante le hablaba y le dijo que no era columna, que es un daño que le hicieron, una maldición y que es muerte, es para muerte, era una maldición para muerte. Él se iba a ir, le iba a agarra una depresión, ya no le importaba nada, si va a morir, muere y si vivo y si me sano, me sano y si me tengo que morir me voy a morir, era así la decisión que tenía. Usted sabe que oró esa noche, oró y dijo que él se iba a sanar, que él se iba a sanar, que se iba a sanar, que se iba a sanar pero oró mucho y bueno yo vine acá y le conté eso a él. Esa noche dijo que le iba a sanar, que le iba a sanar pero algo... Fue tan hermosa esa noche, ese culto que hasta yo sentí y estoy segura le dije y tomé esa palabra y le dije a mi hijo que 'Dios te va a sanar, te va a sanar' y era una maldición usted sabe. A.: $-¿$ Y así una persona como ella puede darse cuenta si alguien tiene un espíritu malo o bueno?

G.: -Si le va a decir todo, ella la hermana le va a decir.

En contraste con este modo de concebir las relaciones entre la gestión de la salud y la enfermedad y los vínculos con las potencias no-humanas, los misioneros no

\footnotetext{
53 Donde todas las personas poseen en algún tipo de vínculo con entidades poderosas no-humanas, siendo la diferencia con el shamán de grado.

54 De hecho, se encuentran sometidas a los mecanismos de control social característicos de los grupos aborígenes chaqueños que buscan evitar la acumulación excesiva de poder o liderazgo: el rumor, las acusaciones de brujería o de tener pactos con los demonios.
} 
aborígenes, de forma muchas veces no intencional, intentarán introducir la idea del origen «natural» de la mayor parte de las enfermedades. En este sentido, Miller ${ }^{55}$ hará referencia a como los misioneros menonitas abordaban las enfermedades de los aborígenes como fenómenos naturales que no requerían de intervención sobrenatural y que se los trataba solo con aspirinas o inyecciones. De ese modo, la enfermedad quedaría fuera del ámbito de incumbencia del discernimiento de espíritus. No obstante, en la práctica los propios misioneros menonitas se vieron llevados a acompañar muchas veces las concepciones mocoví sobre salud y enfermedad ${ }^{56}$. Esto por ejemplo, puede observarse en la participación de los menonitas en sesiones de curación realizadas en el contexto de los cultos aborígenes.

\section{EL CULTO}

Así como la obtención personal de «dones» del Espíritu Santo y la comunicación directa con lo sobrenatural tienen importantes puntos de contacto con el universo shamánico, algo similar ocurre entre los cultos evangélicos y la ritualidad shamánica. Esto se debe a que la naturaleza extática de los mismos proporcionó nuevos canales para la resignificación de las experiencias shamánicas.

Los cultos evangélicos son una experiencia religiosa central y un lugar sumamente importante para la socialización. Tienen una duración variable entre tres o cuatro horas e incluyen danzas, canciones, oraciones de alabanza, prédicas, testimonios de creyentes y pastores, lecturas bíblicas y sesiones de curación ${ }^{57}$. El énfasis en las canciones y el rezo esta vinculado a que estos son vías privilegiadas para la experimentación del gozo (netoonaxac). La categoría polisémica de gozo ha permitido articular experiencias extáticas que incluyen algunos aspectos del universo tradicional shamánico.

Para los mocoví, el gozo comprende un sentimiento de emoción y de comunión con el Espíritu Santo que inunda al fiel con su poder. La experimentación del gozo puede verse reflejada en una serie de imágenes sensoriales que acompañan la experiencia de lo numinoso ${ }^{58}$. Por ejemplo, varios creyentes refieren sensaciones de calor, escalofríos o llanto. Creemos que esto se debe a que los sujetos durante los cultos desarrollan lo que Csordas ${ }^{59}$ denomina un particular «modo somático de atención» ${ }^{60}$. Es decir, los creyentes no sólo son socializados en determinados géneros discursivos -como por ejemplo el testimonio- sino también en «modos sensoriales distintivos de

\footnotetext{
55 Miller 1977, 4-5.

${ }^{56}$ En el caso de misioneros provenientes de iglesias pentecostales, sus nociones de salud y enfermedad se articulan con más facilidad con las concepciones mocoví.

57 Miller 1979, 122-128.

58 Citro 2000, 50-52.

59 Csordas 1993, 138.

${ }^{60}$ Este concepto es definido por dicho autor como formas culturalmente elaboradas de atención «de»y «con» el propio cuerpo de todo lo que está alrededor, incluyendo la presencia corporizada de otros.
} 
percepción corporal» ${ }^{61}$ que a su vez los modelos discursivos refuerzan, dando lugar a una verdadera educación del sentimiento. Por otra parte, la categoría de gozo resulta central ya que es una marca de legitimidad de lo verdaderamente evangélico, y por lo tanto se vuelven de gran importancia las referencias al grado de gozo presente en las distintas prácticas, situaciones, etc.

Para los menonitas, las experiencias de gozo también van a ser de suma importancia y la conceptualizarán como una experiencia de éxtasis. En este sentido, van a distinguir entre el «gozo negativo» como aquello que debe «salir del cuerpo» antes de convertirse al evangelio y el «gozo positivo» como aquello que debe ingresar al cuerpo $^{62}$. Así por ejemplo, en el «Manual para ministros» se va a instar a hacer una selección: «¿Hay que dejar de creer como antes para creer en Jesucristo? La respuesta es: hay que seleccionar» ${ }^{63}$. En la misma línea los menonitas también esperan mesura en las experiencias del Espíritu y el «Manual para ministros» sugiere mesura y prudencia, lo cual no es muy característico de las experiencias extáticas mocoví. Entre estos es justamente en el contexto del contacto con las potencias no-humanas que se considera lícito y esperable el exceso en el comportamiento humano. Los mocoví tienen en su trato habitual un gran control sobre las emociones y la gestualidad. Pero las experiencias «potentes» (la borrachera, la danza, el encuentro con los poderosos, el culto) dan lugar a una liberación de las mismas.

Por otra parte, con el objetivo de poder unificar la estructura del culto y regular las expresiones que acontecen durante el mismo, en el «Manual para ministros» encontramos sugerencias y «modelos de ceremonia». Así por ejemplo, en el capítulo «El Culto» ${ }^{64}$ hay una breve descripción de la alabanza, la danza, la lectura bíblica -incluidos aquellos pasajes más comunes-, agradecimientos, etc. A pesar de estos intentos por normar el culto, para los mocoví la estructura del mismo se va a definir en gran parte durante la performance.

Algo similar observa García ${ }^{65}$ en su análisis sobre los cultos wichí. Este autor señala que la sucesión de acontecimientos durante el culto como así también la emotividad asociada a ella va a estar abierta a la eventualidad y será negociada en cada caso concreto.

Consideramos que lo que el autor denomina política de «agenda abierta» ${ }^{66}$ nos es útil para pensar el modo en que acontece el discernimiento de espíritus durante los cultos evangélicos mocoví. En este sentido, en la práctica el discernimiento de espíritus no es realizado únicamente por el pastor sino mediante la interacción cara a cara del conjunto de los creyentes durante el culto. Esto podemos observarlo en un relato de Gregoria sobre un matrimonio que había ido de visita al culto. Ella nos dijo:

\footnotetext{
${ }^{61}$ Citro 2000, 46.

62 Loewen, Buckwalter et al. 1965, 27s.

63 Equipo Menonita 2006, 103.

${ }^{64}$ Equipo Menonita 2006, 14-26.

65 Garcia 2005, 226.

66 Garcia 2005, 227.
} 
Había un hombre de Santa Fe una vez acá, un hombre venía con la señora dice que le agarró y le robó una señora, una mujer vamos a decir le sacó a una señora otro hombre, un matrimonio, vino acá había preguntado del evangelio, es decir que era evangelista. Vinieron esa noche y nos presentó el evangelista de Santa Fe yo le dije: 'de Santa Fe hay algo en él que no es, no era evangelista, era mensajero'. Al no aceptar mi marido dice: 'no, no’. ¿Por qué será? Bueno lo dejaba hacer porque tampoco le vamos a decir: 'no, no lo traigas', porque nosotros no sabemos, el que puede decir solamente, el único, es el Espíritu de Dios. Va a descubrir algo y así fue. Esa noche usted sabe, un hermano sin conocer la tomó una hermana el Espíritu de Dios y empezó a hablar y le dijo que no era de Dios que 'cómo venís engañando' le dijo y nada 'estas en pecado', todo eso le dijo. Y así pasó con ese matrimonio, muchos se enojaron porque no lo hizo pasar a él y bueno. Pero gracias porque Dios le reveló también a ellos. Aquellos que se enojaron contra mi marido después se dieron cuenta que no eran.

En este relato, podemos analizar el culto como una performance en la que interactúan varios participantes cara a cara. Durante la misma es que se va a ir definiendo el rumbo de la acción y negociando en cada intervención si el matrimonio que estaba de visita era de Dios o no. En este sentido, podemos ver como en un primer momento serán Gregoria y su marido los que duden del matrimonio pero queda abierta la posibilidad de que participen durante el culto. Es a partir de esa interacción que la comunidad de fieles va a negociar un consenso, expresado como un sentimiento de la comunidad de fieles que permite discernir. Como ya hemos mencionado, este consenso construido en las interacciones cara a cara hunde sus raíces en situaciones previas. En el ejemplo que nos ocupa, la duda inicial de Gregoria y su marido se fundamenta en una «revelación» divina que había tenido este último durante un sueño ${ }^{67}$ :

Yo me acuerdo la vez... cosa Dios lo reveló este...mi esposo que estaba de festejo acá la iglesia ese tiempo dijo a los dos días antes: 'vendrán un matrimonio pero no son de Dios y tengan mucho cuidado'. Le dijo eso como un sueño vamos a decir y bueno, a los 3 días llegó el sábado, apareció y cuando él la vio la impactó, 'esos son' dice que dijo. Sintió, algo que sintió algo que no, esos son. Y esa noche llegó al culto. ¡Ay hablaban en lengua una cosa como para decir que usados por Dios y no era de Dios! Y él no le dio la oportunidad y se enojaron porque no le dieron la oportunidad siendo que vino a pasear y no le dio oportunidad.

En el relato de Gregoria podemos observar como a partir del «encuentro» con Dios durante una experiencia onírica y gracias a la obtención de conocimiento es que su marido puede discernir y reconocer que aquellas personas que iban al culto

\footnotetext{
${ }^{67}$ Como ya hemos mencionado, para los mocoví los sueños, constituyen una experiencia clave ya que son espacios donde los humanos pueden tener encuentros con poderosos. El mundo onírico es sumamente importante en la conformación de la vida cotidiana y es un elemento central en el habitar existencial guaycurú.
} 
«no eran de Dios». Dicho discernimiento debe ser luego puesto en juego en el contexto del culto para construir performáticamente un consenso que lleve a un discernimiento de la comunidad del culto en su conjunto. En este sentido, el «Manual para ministros» ${ }^{68}$ nos muestra como si bien los menonitas no buscarán el monopolio de la determinación de los verdaderos místicos (cuestión vinculada a las diferencias eclesiales entre católicos y menonitas y al giro post-colonial de los misioneros menonitas contemporáneos), sí sugerirán que sean los pastores de las iglesias quienes decidan.

\section{CONCLUSIONES}

A lo largo de este trabajo hemos buscado analizar las formas que adquiere el discernimiento de espíritus en el contexto de las iglesias evangélicas mocoví en el Chaco argentino. En este sentido creemos que dicha exploración no sólo aporta al conocimiento específico de la experiencia evangélica mocoví, sino que también puede contribuir a ampliar el conocimiento sobre el discernimiento de espíritus como dispositivo de regulación del carisma cristiano. En este sentido creemos que, dada la relación fundamental entre discernimiento de espíritus y estructura eclesial, abordar esta temática en el caso del cristianismo en las periferias coloniales ilumina de modo novedoso el modo en que este dispositivo actúa.

Para abordar este objetivo, en primer lugar retomamos los aportes recientes que han buscado construir una historia social del discernimiento con el fin de dar cuenta de como, a lo largo de la historia del cristianismo, el discernimiento de espíritus se constituyó como un dispositivo teológico fundamental en la lucha por el acceso legítimo al carisma. Pero particularmente, para enfatizar la forma en que la experiencia subjetiva e intentos normativos o disciplinarios cobraron importancia en función de los cambios en los modelos eclesiales dominantes en cada período y región. Vimos como, en el viejo mundo las tensiones entre concepciones «proféticas»o «carismáticas» de la autoridad religiosa y otras más «jerárquicas» y «sacerdotales» inclinaron la balanza entre formas del discernimiento más ligadas a la subjetividad individual y la interacción intersubjetiva cara a cara y modos burocratizados y normados de la misma.. En segundo lugar, analizamos a partir de nuestro material etnográfico, el movimiento del evangelio entre los mocoví del Chaco Austral, ya que creemos que en el cristianismo contemporáneo son fundamentales las tensiones entre formas particulares del mismo surgidas en las periferias coloniales con dinámicas sociales vinculadas en gran medida a las características de esas sociedades y los modos de construir iglesia propios de la experiencia cristiana europea y norteamericana. Por ello nuestro análisis presta particular atención a la estructura social de estas iglesias, en un marco colonial y postcolonial; analizamos las concepciones presentes en las mismas sobre los vínculos con las potencias no-humanas; la gestión de salud y enfermedad; y la experiencia del culto. En este sentido hemos dado cuenta de la

\footnotetext{
${ }^{68}$ Equipo Menonita 2006, 101.
} 
compleja interacción entre modos mocoví previos a la acción misionera no aborigen y concepciones derivadas del intento misionero por dotar al cristianismo guaycurú de un cierto tipo de unidad, encarnada en el esfuerzo por constituir y sostener la Iglesia Evangélica Unida.

Creemos que la combinación entre una perspectiva histórica con una metodología etnográfica nos ha permitido por una parte, reafirmar el carácter clave del discernimiento de espíritus como un dispositivo que ha articulado los debates cristianos referidos al poder legítimo en el seno de las iglesias. Por otra parte, nos ha permitido dar cuenta cómo a lo largo de la historia del cristianismo dicho dispositivo ha tomado características vinculadas a las particularidades de la estructura de organización eclesial.

En este sentido, en el contexto del evangelio mocoví, veremos que primarán las lógicas de parentesco, y el carácter comunitario y centrado en el culto local del ejercicio del discernimiento. Más allá de los intentos misioneros de asignar al pastor el carácter de especialista, será la pequeña congregación local el verdadero agente del discernimiento. Si bien el criterio dominante parece ser el de la experiencia subjetiva, esta no es la de un individuo aislado, pensado como un agente independiente, sino que se trata de una experiencia que si bien reside en el individuo se modela fuertemente en la experiencia colectiva de negociación, durante las interacciones cara a cara.

En este sentido, a diferencia de lo que sucede en sociedades jerarquizadas con una estructura de poder centralizada, en las sociedades aborígenes chaqueñas no vamos a encontrar la figura de grandes profetas que transmiten mensajes a una nación o personas que ocupen cargos eclesiásticos que busquen detentar el monopolio de ciertos dones. Esto no sólo se verá limitado por el carácter congregacional de las iglesias, el cual va a acotar los posibles intentos de acumulación de liderazgo, prestigio o poder sino también a través de otros mecanismos de control como el rumor, el chisme o las acusaciones de brujería.

La tendencia centrífuga de las iglesias mocoví estará en tensión con los intentos misioneros de regular y unificar la experiencia cristiana aborigen. Dicha experiencia es vista por los misioneros de una forma ambigua. En una dirección se reconoce en ella una tendencia al exceso y a la presencia de elemento «paganos» o incluso potencialmente diabólicos. En otro sentido, el entusiasmo y la entrega de los creyentes aborígenes los sitúan para los misioneros en el campo de una esperanza de «reavivamiento» de su propia experiencia de fe y de la del cristianismo universal. Por otra parte la experiencia religiosa moqoit incluye una compleja búsqueda de establecer los pactos más ventajosos posibles con entidades suprahumanas. En dicho contexto el Dios cristiano se presenta como una alternativa especialmente potente y la negociación con los criterios de discernimiento y exclusividad que los misioneros proponen es una realidad cambiante en diálogo permanente con las lógicas preexistentes.

En este contexto, las preguntas típicas del discernimiento de espíritus tal como es practicado en los cultos evangélicos moqoit serán: ¿Quién es este poderoso que se me presenta? ¿Qué me ofrece? ¿Qué me pide a cambio? ¿Con quién me conviene pactar? Si pacto con este ¿Puedo pactar también con otro poderoso? 


\section{BIBLIOGRAFÍA}

A. Altman, «Historia y conversión: el evangelio entre los mocoví del Chaco Austral», RUNA. Archivo para las Ciencias del Hombre, 322 (2011) 127-143.

L. Buckwalter y A. Buckwalter, «Misión a las comunidades autóctonas. Un testimonio personal», En: W. Horst, U. Mueller-Eckhardt y P. Frank (eds), Misión sin Conquista. Acompañamiento de comunidades indígenas autóctonas como práctica misionera alternativa Buenos Aires, (2009) 196-203.

P. Bourdieu, Esquisse d'une theorie de la practique, París, 1972.

J. Braunstein, Algunos rasgos de la organización social de los indígenas del Gran Chaco, Buenos Aires, 1983.

N. Caciola, Discerning Spirits: Divine and Demonic Possession in the Middle Ages, Ithaca, 2003.

F. A. Campagne, Poder y religión en el mundo moderno: la cultura como escenario del conflicto en la Europa de los siglos XV a XVIII, Ciudad Autónoma de Buenos Aires, 2014.

C. Ceriani Cernadas, Dilemas étnicos y políticos en la experiencia religiosa toba (qom), VIII Reunión de Antropología del MERCOSUR, Buenos Aires, Argentina (2009).

C. Ceriani Cernadas y S. Citro, «El movimiento del evangelio entre los tobas del Chaco argentino. Una revisión histórica y etnográfica», En: B. Guerrero Jiménez (ed.), De indio a hermano. Pentecostalismo indígena en América Latina, Chile, (2005) 111-170.

S. Citro, «La materialidad de la conversión religiosa: del cuerpo propio a la economía política», Revista Ciencias Sociales, 10 (2000) 37-55.

S. Citro, Cuerpos significantes. Travesías de una etnografía dialéctica, Buenos Aires, 2009.

T. J. Csordas, «Somatic Modes of Attention», Cultural Anthropology, 82 (1993) 135-156.

Equipo Menonita, Manual para ministros en las Iglesias evangélicas indígenas del Gran Chaco de la Argentina, Formosa, 2006.

M. A. García, Paisajes sonoros de un mundo coherentre. Prácticas musicales y religión en la sociedad wichí, Buenos Aires, 2005.

J. Goody, (ed). «Cultura escrita en sociedades tradicionales», Barcelona, 1996.

S. Gruzinski, El pensamiento mestizo, Barcelona, 2007.

INDEC, «Encuesta Complementaria de Pueblos Indígenas 2004-2005 - Complementaria del Censo Nacional de Población, Hogares y Viviendas 2001», http://www.indec.mecon.ar/ webcenso/ecpi/pueblos/ampliada_index.asp?mode=09 [acceso 20.05.2014].

J. Loewen, A. S. Buckwalter y J. Kratz, «Chamanismo, enfermedad y poder en la vida de la Iglesia Toba», Practical Anthropology, nov.-dic. (1965 [trad. 1997]) 250-280.

A. M. López, «La Virgen, el Árbol y la Serpiente. Cielos e identidades en comunidades mocovíes del Chaco», Tesis de doctorado, Facultad de Filosofía y Letras, Universidad de Buenos Aires, (2009).

B. McGinn, «'Evil-sounding, Rash, and Suspect of Heresy’: Tensions between Mysticism and Magisterium in the History of the Church», The Catholic Historical Review, 902 (2004) 193-212. 
E. S. Miller, Unintended effects of protestant missions on aboriginal populations of the Gran Chaco. The Impact of National Development on the Indians of Tropical South America, University of Wisconsin, 1977.

E. S. Miller, Los tobas argentinos. Armonía y disonancia en una sociedad, México, 1979.

W. J. Ong, Oralidad y escritura. Tecnologías de la palabra, Buenos Aires, 1996.

S. Parker, Led by the Spirit: Toward a Practical Theology of Pentecostal Discernment and Decision Making, Sheffield, 1996.

W. D. Reyburn, The toba indians of the argentine chaco. An Interpretive Report, Elkhart, 1954.

M. Rubin, «Europe Remade: Purity and Danger in Late Medieval Europe», Transactions of the Royal Historical Society, 611 (2001) 101-124.

B. Susnik, Dimensiones migratorias y pautas culturales de los pueblos del Gran Chaco y de su periferia. Enfoque etnológico, Resistencia, 1972.

F. Tola, «Personas corporizadas, multiplicidades y extensiones: un acercamiento a las nociones de cuerpo y persona entre los tobas (qom) del chaco argentino», Revista Colombiana de Antropología [en línea], 41 (2005) 107-134.

F. Tola, Les conceptions du corps et de la personne dans un contexte amérindien. «Je ne suis pas seul(ement) dans mon corps». Indiens toba du Gran Chaco sud-américain, Paris, 2009.

F. Tola, Yo no estoy solo en mi cuerpo: cuerpos-personas múltiples entre los tobas del Chaco argentino, Buenos Aires, 2012.

P. Wright, «Crisis enfermedad y poder en la Iglesia Cuadrangular Toba», Cristianismo y Sociedad, 28/3 105-Pentecostalismo y milenarismo (1990) 15-37.

P. G. Wright, Ser-en-el-sueño. Crónicas de historia y vida toba, Buenos Aires, 2008a.

P. G. Wright, «¿Y yo qué clase de poder tengo?» Liderazgo y dilemas shamánicos en la modernidad toba», Liderazgo, representatividad y control social en el Gran Chaco, J. Braunstein y N. Meichtry, Editorial Universitaria de la Universidad Nacional del Nordeste, Corrientes (2008b) 139-146. 